BENITA SIMATI-KUMAR

\title{
The Potential of Vā Part 1: Working in the space between
}

\section{Abstract}

This article is part of a series of articles that composed an exegesis, submitted in fulfilment of the requirements for the degree of Doctor of Philosophy. The series is a narrative of discovery through practice-led research. Each article reveals its purpose and significance that leads into the next series, which then eventuate to that final design proposal.

The exegesis is presented in this format, to break down the components that assisted in practice-led research. Each article can be read and unpacked on its own as a learning tool. The purpose of this edited series is for the exegesis to be more accessible and adaptable creatively to those being introduced to practice-led research.

The Potential of Vā Part 1: Working in the space between, presents the contents and an introduction of the exegesis, it positions the research by placing the present investigation in the context of the 
writer's previous work. This article outlines the contemporary artistic context in which this thesis exists, it also presents in detail the methods employed in the first phase of the research, and the use of traditional knowledge to form the Lala-Vā model framework.

\section{Introduction}

Research that takes the nature of practice as its central focus is called 'practice-based' or 'practiceled' research. It is carried out by practitioners, such as artists, designers, curators, writers, musicians, teachers and others, often, but not necessarily, within doctoral research programmes. This kind of research has given rise to new concepts and methods in the generation of original knowledge (Candy, 2006, p. 2).

I must acknowledge that this creative, practice-led research is not conducted in the field of Art and Design. Although my background is grounded within Art and Design, specifically Spatial Design, this research has been creatively incorporated within Te Ara Poutama, Faculty of Māori and Indigenous Development. I have based the research in this faculty as Te Ara Poutama at the Auckland University of Technology (Portes \& Rumbaut) is more than a learning space, it is a community. It encompasses the idea of whakapakari - which means to discover, evolve and grow. I wanted my research to evolve within a community of indigenous 
knowledge and discover new means of understanding.

\section{Position of research}

This section locates the research project in two realms of practice. The first is the existing creative work of my research and the second is the practice among indigenous artists who have worked with the concept of vā.

\section{Positioning the researcher}

In this section, it is important for me to locate the place where my cultural identity originates from, and secondly, to highlight the significance of my identity within my design practice. I was born and raised in New Zealand and I am of Sāmoan and Fijian Indian descent. I have always felt a strong sense of belonging to my indigenous Sāmoan culture, which has been nurtured and mediated through my Sāmoan mother and our Sāmoan Church community in South Auckland. However, like many other New Zealand-born Pacific Islanders, I grew up struggling with my blended identity.

Growing up, I perceived the Sāmoan/Pālagi blend as more positive than the Sāmoan/Fijian Indian blend. At primary school, I would introduce myself and my ethnicity and the teacher would reply: 'Oh you're just another fruit salad'. In my head I would respond; 'No! I'm not a mixed tin of fruit'. But what other ways might I have been described? Half-caste? 
Mixed breed? Or the popular Sāmoan term afakasi (half-caste)? I knew who I was, but defining my ethnicity in relation to my identity was another obstacle.

I was brought up with a strong sense of Sāmoan identity, but was confused and baffled when asked about my Fijian Indian identity. Unlike my brother and sisters, I was told I looked more Indian. Growing up, I took offence when told I looked more Indian because I perceived this to be a negative attack on my appearance. Yes, I may have looked Indian in their eyes but I was Sāmoan, why could they not see that? It had played such a negative role in my life that I was almost ashamed at times to tell people I was half Fijian Indian. Having grown up with a nonexistent Fijian Indian culture and being tested by my peers as to how Sāmoan I was, I struggled with my identity.

Looking back on my childhood, I recall all of the mixed emotions that I experienced whilst growing up and discovering who I was. I experienced both the positive and negative attitudes within society. As an adult, I am writing what I think is significant commentary about blended identity for Pacific youth living in Aotearoa/New Zealand. Yes, I am Sāmoan. Yes, I am Fijian Indian. And today I am very proud of my blended identity. There are more and more people in this world born and raised with blended identities that have to constantly negotiate their 
identity in terms of ethnicity and place. This research speaks to them.

Why are we constantly pressured to identify ourselves and where we belong? Are we as a society celebrating and acknowledging our cultural differences? What is it that we hold on to and surround ourselves with that remind us of home and culture? What are the spatial environments that comfort us and put us in context in terms of who we are and where our ancestors come from?

My practice and background is within Spatial Design. I am interested in the diasporic spatial environments of blended Pacific identities in Aotearoa/New Zealand. Part of the initial process for this research has been to analyse and discuss the theoretical framework of a Sāmoan concept known as vā. This has allowed for a more self-reflective practice, and has given me the opportunity to review this work through a deeper Pacific cultural awareness. This self-reflective phase is located within the methodology where I will discuss the significance of my design processes and how they are reflective of the theoretical framework.

\section{Forerunners}

During most of my undergraduate tertiary studies, I did not have any interest in Pacific theory or design, but in my final year as an undergraduate, I came across this term, 'vā'. Albert Wendt (1996) explains 
that, 'vā is the space between, the between-ness, not empty space, not space that separates but space that relates, that holds separate entities and things together in the Unity-that-is-All' (p.1). For me, Wendt's beautiful and poetic description captured the essence of this term in a post-colonial global context, but it also raised questions regarding its meaning in relation to my design practice.

In 2009, in my final year of undergraduate study, a studio paper entitled Paradise - Life's a Beach (or, All the World's on Show) written by Dr Tina EngelsSchwarzpaul marked the beginning of a long, thought-provoking relationship with the concept of vā. The studio project', located at the Tropical Islands Resort dome in Germany, assessed strategies and scripts used to depict, suggest or simulate Paradise. My project was an exploration of lalava (lashing) and how this created my own view of the vā, the vā being the relationships that consistently define and redefine themselves in the space between two cultures. The vā consists of relationships between people and things (e.g. tropical island tourists and the fale (house) Sāmoa), unspoken expectations and obligations between tourists and their environment

The key element of the design was based the deconstruction and architectural form of the fale Sāmoa. Each piece was different and carried its own individual meaning in relation to where it was placed within a fale. Each piece had been lashed, 
bound, bleached, tied, dyed, smoothed and constructed as if they too were part of a fale.

Placing these deconstructed forms around the Tropical Islands Resort dome, meant that they were displaced, and in turn this replicated the notion of unfolding the lalava, and creating an intervention of interest and awareness. When following the path of these displaced forms, one already becomes part of the vā that I had created leading to the fale inside the dome. One then needed to manoeuvre their way through the vā to discover the true beauty within this displaced Sāmoan fale

What became apparent in this studio paper, was that the intervention I designed was both complex and difficult to understand as it was in reference to Sāmoan culture and understanding of? Its complex origins of connections. The vā in this project did not have a straight forward meaning, but was highly significant in terms of understanding spatial relationships. It was not to be seen as a vacant space nor as a space that needed to be filled. It was a space of woven connections; a duality of substance and respect.

In 2010 , I had become so influenced by the potential of vā, that I enrolled in an Honours year to further pursue this concept in my practice. In this project, I drew my own experiences of a Sāmoan burial ceremony. I proposed to activate the vā within the context of a diasporic Sāmoan community in Auckland, and examined possible ways of thinking 
about between-ness, non-empty space, and relationships (Wendt, 1996) to create a communal space of belonging. The honours exegesis explored ways of visualising the relational spaces that the vā creates through the experience of Sāmoan customary spatial practices and rituals. The design outcome was an architectural form created from the process of 'stirring the vā', again the process of LalaVā, stirring the relationships within space, testing the potential of vā through the various methods of experimentation, drawing, lashing and folding.

An important question guiding this honours research was how Pacific perspectives on fonua, moana and tagata (relationships between land, sea and people) can activate culturally responsive architecture in a diasporic environment

The success and praise from supervisors in my honours year led me to further test the potential of vā in a Master's degree in 2011. The project examined the associations and ancestral connections of ie tōga (fine mats) within Sāmoan communities. It explored the relationships created through the exchange of historical 'ie tōga, making visible their place in the vā and how they activate it by presenting to us our past, present, and future The design proposal was the creation of a space of display arising from the processes of lalaga (weaving) and lalava (lashing). According to Albert Refiti (2010, personal communication), 'stirring the vā' is a literal translation of Lala-Vā, lashing. In this 
case, the combinations (lalaga/ lalava/ vā) lead to a stirring and reconnecting of the relationships within diasporic space. The Masters thesis resulted in a proposed intervention within the South Auckland community. This intervention was a celebration and display of archived and family owned ie togga. The function of the display enhanced the vā relations within the community by engaging people and ie tōga. The vā was acknowledged in the presence and participation of the community.

It was during these projects (Honours and Masters) that I developed the process of Lala-Vā as a methodology of practice. This concept given to me by my supervisor at the time, Dr Albert Refiti, was something new. I then took it upon myself to develop and adapt this to my own creative practice research in an effort to find a more culturally relevant way to design for my Sāmoan diaspora community.

In both these projects the concept of vā and the methodology of Lala-Vā were the driving forces in my practice as a spatial designer. Lala-Vā respectfully and creatively captured the cultural element necessary to communicate and relate to the Sāmoan diaspora. At the end of these projects I began to reconsider the potential of vā as something more than a Sāmoan concept, to something that could be adapted and communicated to a much wider Pacific community. I became interested in the possibilities it could have for Pacific diaspora communities. However, when contemplating the complex cultural, 
ethnic and historical intersections of these Pacific diaspora communities, I realised that this would not be a simple task.

Reflecting on both projects, I thought about Sāmoan fa'alavelave (ceremonial and other family obligations), because I found it personally difficult to understand the significance of the cultural ceremonies that took place. For example, at my Aunty's funeral, a si'i (ceremonial exchange of gifts) took place at her home. My role specifically was to carry out feau (business, errand, task, message). Within this role I had to know my place within the vā relations that emerged out of the ceremony. This experience raised some questions for me. What did this experience mean to me culturally? Without fully understanding the meaning and significance of this ceremony, how might I carry on these traditions? What was the true value of the ie togga?

Experiencing these cultural practices was fulfilling. The amount of effort put into the event was immense; the large quantities of food prepared, the value of gifts presented, and the importance of the orators reciting each exchange played a significant role to the traditional ceremony. But would I carry on these traditions if I had the choice? How do we, as the next generation, view these cultural ceremonies as 'blended' diaspora? How do we carry out the traditions? I do not want to necessarily propose change, but I do want to explore and understand different views and perspectives from 
those people of blended backgrounds. How could my skills as a designer explore new methods of valuing 'blended' Pacific culture in Aotearoa? I felt the exploration and conceptualising of the term vā had something to offer spatially to this community.

This research project looks at Pacific diaspora communities in Auckland, specifically, those of blended cultural and ethnic identities. Aspects I have pursued further in my project within the broad concept of vā are Lala-Vā, qualities of relational space, location and diaspora, Pacific traditions, and Pacific knowledges and cultures. These parts will be explored through notions of display or exhibition interventions, which discover how we encounter spaces that serve to put something on show or view (Kirshenblatt- Gimblett, 2000). Important aspects to research are how people perceive such spaces and what cultural issues arise from them. The processes of the research will be informed by the notion of Lala-Vā as 'stirring the vā', literally meaning stirring the relationships within space and testing the potential of changing the vā through various methods of experimentation.

\section{Research Methodology}

Methods employed in first phase of the research

The methods employed in this phase include:

-Respectful introduction

-Interviewing

- Consultation with indigenous scholars 
- Gathering peer review as the research progresses

\section{Respectful introduction}

It was important that the participants felt comfortable with my research. Although the project was accompanied by formal AUT ethics protocols, the research required something more culturally appropriate than simply informed consent. I greeted the participants in the Sāmoan custom by showing respect. The act of courtesy must be shown at all times when communicating with an elder, especially somebody who considers you to be a stranger. The tone of my voice as the researcher and the way I present myself are important because the participants must feel comfortable while in my presence and not intimidated by my words, actions and/or gestures. The participants needed to feel at ease with the aims and proposed outcomes of the project and they also needed to feel comfortable with me photo-documenting their personal spaces.

\section{Interviewing the participants}

I recorded all audio data on my personal Iphone $6 \mathrm{~s}$, and used a Canon EOS 650D for photo documentation. When approaching the participants in their homes or other locations, I was mindful that for most, this experience was probably new and, at first, potentially intimidating (Toluta'u, 2015a). Therefore, I designed the interview so that the participants could speak freely, and so that the 
questions were open ended. This was so the talanoa (Method of enquiry or to talk) could surface without feeling confined or restricted.

\section{Consultation with indigenous scholars}

I was able to access certain indigenous scholars through family and academic networks. These indigenous scholars were either working in universities, ministers, community leaders, or retired school teachers. I was able to email or call them directly and arrange meetings. I sent them an abstract of my research, and arranged a time to meet with them where they felt comfortable talking. My main focus in these meetings was to understand their thoughts about my practical component (manifestation of vā) for this research, and with their agreement I was able to take notes of their ideas and views.

Gathering peer review as the research progresses Adjacent to the methodology was the gathering of advice and critique of the research. In the academic realm research progress has involved presentations of my thinking in progress at conferences and in reading groups. Here, experts and academics considered my ideas and artistic expression and offered advice and contextual information.

I also sought the help and advice of Sāmoan academics with regard to specific terms and 
concepts I was employing in my research. Finally, specific elements of the project and developing research were delivered at seminars and conferences, and in publications.

These included:

- Engles-Schwarzpaul, T. \& Simati-Kumar, B. (2011). A fale Sāmoa at Tropical Islands Resorts: Germany - Performing Sämoa to the world. Sāmoa Conference II, The National University of Sāmoa.

- Simati-Kumar, B. (Simati-Kumar). The potential of Vā: An investigation of how 'Ie Tóga activate the spatial relationships of the Vā , for a Sāmoan diaspora community. Fourth Annual Meeting of the Native American and Indigenous Studies Association Conference, Moehgan Sun Convention Center, Uncasville, CT.

- Simati-Kumar, B. (Simati-Kumar). The potential of Vā. Te Kaharoa - The e-Journal on Indigenous Pacific Issues. 5(1) 115-137 (100\%)

- Simati-Kumar, B. (Simati-Kumar). The potential of Vā - Transforming Sāmoan and Pacific communities in the diaspora. Te Kaharoa: The e-Journal on Indigenous Pacific Issues, issue and volume etc needed (100\%) 
- Simati-Kumar, B. (2013). The potential of Vā. Maori and Pacific Postgraduate Students Wānanga Series, Nga Wai o Horotiu Marae, Auckland University of Technology. New Zealand.

- Simati-Kumar, B. (2014). How does the next generation of Pacific diaspora from Blended backgrounds construct and maintain their identities through the spaces they inhabit? .PGR 9 Presentation, Nga Wai o Horotiu Marae, Auckland University of Technology. New Zealand.

The advice and critique from papers and artwork I presented at these conferences enabled me to access scholarly responses and engage my thought process with broader talanoa surrounding Pacific art and scholarship.

\section{Interviews with diaspora - Reflecting on blended identities in Aotearoa/ New Zealand}

To capture the lived experiences of blended identities in Auckland and Wellington, New Zealand, a qualitative design was used featuring the talanoa research method (Vaioleti, 2006).

The talanoa method was used for a number of reasons. First, it is a common tool of communication that is used by Pacific communities, and second, for ethical reasons given the background of the 
participants and the Pacific worldview, which stems from the Lala-Vā model.

\section{Qualitative interviews}

A qualitative enquiry was best suited for the purposes of the research, as I was interested in exploring the voices and experiences of blended identity participants. The qualitative approach is concerned with how people construct their realities, their experiences and the meanings they assign to these realities (Merriam, 2009). This approach is driven significantly from this process orientation toward the world (Maxwell, 2013) and enables those participating to present 'inside out' perspectives of the phenomena being explored (Flick, Kardorff, \& Steinke, 2004). Qualitative research also honours and accepts that the social setting in which a person is placed is unique and complex (Hatch, 2002) and therefore, can be applied to a variety of contexts. The flexibility of qualitative research also facilitates the inclusion of the cultural beliefs and practices of participants - in this case they are blended Pacific participants - into the research process. Maxwell (2013) summarises five goals of qualitative research, which are applicable to this research. These include that qualitative research explores people's realities; it investigates people's individual meanings drawn from their experiences; it considers the context in which they experience this meaning; and the influence of context as well as the process in which 
they experience it. Lastly qualitative research ensures the researcher, is aware of the risks of uncovering any unanticipated factor (Maxwell, 2013).

\section{Talanoa}

Storytelling, oral histories, the perspectives of elders and of women have become an integral part of all indigenous research. Each individual story is powerful. But the point about the stories is not that they simply tell a story, or tell a story simply. These new stories contribute to a collective story, or tell a story simply. These stories contribute to a collective story in which every indigenous person has a place....

For many indigenous writers stories are ways of passing down the beliefs and values of a culture in the hope that the new generations will treasure them and pass the story d down further. The story and the story teller both serve to connect the past with the future, one generation with the other, the land with the people and the people with the story. As a research tool, Russell Bishop suggests, storytelling is a useful and culturally appropriate way of representing the 'diversities of truth' within which the story teller rather than the researcher retains control (Smith, 1999, pp. 144-145).

I wanted to ensure my research approach resonated well within the Lala-Vā model (see 'Traditional Knowledge' section). I considered talanoa as a culturally appropriate way of communicating with the participants. Talanoa was therefore ideal for this in-depth enquiry and reinforced the importance of using a Pacific knowledge-sharing tool to research 
Pacific knowledge. The interpretive method of talanoa, like phenomenology, views peoples realities as socially constructed (Geoff, 2006). The talanoa model of research is based on its meanings in Sāmoan, Tongan and in other Pacific Languages. In short, talanoa means to have a conversation, to relate something, or to talk story (Ministry of Social Development, 2005).

The talanoa is a traditional method of story sharing and information gathering, where the data collection becomes 'a conversation, a talk, an exchange of ideas or thinking' (Vaioleti, 2006, p. 23). It is culturally appropriate because it fits with the voices of the participants. The use of the talanoa also protects against the well-reported practice where minority groups, such as Pacific people, have been subjected to disempowering research. Furthermore, Western researchers have taken and created what they claim to be the realities of their participants based on their own Western perspectives (Vaioleti, 2006). To counter this, Pacific researchers strongly accentuate the use of indigenous epistemologies and research strategies that are grounded in peoples values, beliefs and how they view the world and ways of knowing (Gegeo \& Watson-Gegeo, 2001). The use of the talanoa was considered an appropriate method of enquiry as it incorporates the holistic nature and practices of Pacific communication and interaction. Its philosophical base is 'collective, orientated towards defining and 
acknowledging Pacific aspirations'(Vaioleti, 2006, p. 26).

Regardless of Western perceptions that oral history is comprised of myths, talanoa has been influential in shaping the identity of people in the Pacific. In this process, the stories mean more than storytelling, and are shared for the purpose of connecting and building knowledge, history and traditional wisdom (Halapua, 2000).

Furthermore, the connection between researcher and participants is nurtured in the talanoa, and ensures a smooth and enriching dialogue that promotes flexibility and encourages critical discussions. Talanoa also produces a spiritual relationship between participants, by strengthening and nurturing the vā, which is fundamental to the social functioning of Pacific peoples. The use of talanoa gives participants the time and space to reflect on and honour their journeys (Ka'ili, 2005), and gives them equal responsibility for what is discussed and how this is discussed. This creates a mutually empowering experience. In addition, I was well aware that my knowledge of the Sāmoan language and culture would encourage and facilitate effective talanoa, as this would make the participant comfortable expressing themselves from a cultural and bilingual perspective. 


\section{Research participants}

Six participants were selected based on their blended Pacific identity. The participants for this research were over 18 years old. The criteria I used to choose who to invite are as follows:

- Female who is over 18 years old

- Descends from at least two Pacific ethnic backgrounds, one of which must be from the Sāmoan Islands, to align with the Sāmoan cultural ideologies employed in this research. The focus of recruiting will be on the Polynesian Islands as well as Fiji.

- Is comfortable with the researcher photodocumenting their space of dwelling (i.e home, office, garden).

- Identifies with the term diaspora.

The primary focus of this research is the experience of those who have blended backgrounds living in New Zealand as part of a diasporic community. Therefore, only the participants with this knowledge were able to contribute to this research. The participants were recruited using the Pacific method of creating links through genealogy or community ties. Potential participants were also encouraged to promote the study amongst their own networks and communities. A potential list of participants was first identified by myself as the primary researcher 
and my supervisor. I, the researcher, then made the initial contact, and followed up with the participants to arrange a face-to-face meeting in which I outlined the research project. During this meeting, I endeavoured to answer any questions that arose. Once participants registered their interest in the research, they received the Information for Participants and Consent Forms.

I am a member of the community being researched. As stated previously in the introduction to this article, I am an engaged member of my Pacific community in Auckland and have experiential knowledge of key Pacific cultural values and norms. Furthermore, I have extensive research experience in Māori and Pacific communities both in New Zealand and in the Cook Islands. Both my primary and secondary supervisors are also of Māori and Pacific descent, thereby providing appropriate guidance in the research. The primary researcher is physically based within the Te Ara Poutama faculty office and is therefore in a key position to seek out consultation with Māori if necessary.

When choosing participants of blended identity it was important and ethically appropriate for me to position myself where both the informant and I were comfortable with the topics and questions that would be discussed in the interview. My research concept of the vā is widely used in the Pacific, which I have conceptualised and framed in a Sāmoan world view, as I am of Sāmoan descent and 
understand it from my cultural standpoint. Therefore, I chose to contact participants who were women and had Sāmoan as a part of their blended identity, to frame and conceptualise the concept of vā.

In doing so, I put myself in a safe environment where myself and the participant were free to express any emotions and feelings on issues that might otherwise be seen as disrespectful. As a young Sāmoan woman, it was important for me to feel safe and comfortable conducting my interviews with suitable participants. For this reason, I was genderspecific and wanted women who could add experience and in depth knowledge to my research, who have raised children but also are at a stage in their career where they are comfortable expressing their unique identity, and who could discuss issues they may have faced growing up as blended Pacific women.

In the series of these articles I will write about each participant as an individual and they will all remain anonymous as per their request. They will be referred to as Tasi, Lua, Tolu, Fa, Lima and Ono.

\section{Traditional Knowledge}

Traditional knowledge: Lalava \& Lalaga

Lalava and lalaga are male and female art forms respectively. Lalava is the lashing by a skilled male, when binding together a fale, a canoe, tools, etc.; and lalaga is the weaving done by women, in the 
form of 'ie tōga. The binding of both lalava and lalaga is the core strengthening within the objects or structure they compose. They are forms of skill from both male and female, and signify the importance that each role has in the aiga (family). Together they form the structure and conceptualise the theoretical framework in this research. In this section, I investigate the strengths of both traditional knowledges, and their relevancy to the methodology and practice of design.

\section{Lalava}

In the exploration of these knowledges, lalava is a useful metaphor. Lalava is about joining and binding material together. Another intention of this technique, according to Tongan artist and tufunga lalava (lashing expert) Filipe Tohi (2006), is to create distinct geometric patterns that were once a wellestablished feature of Pacific culture. Lalava patterns advocated balance in daily living, and were metaphorical and physical ties to cultural knowledge. In his practice, Filipe Tohi expresses his desire to construct and deconstruct. He writes: 'I see everything around me as pattern, structures capable of being broken down and it makes me think about the illusion of things' (Tohi, 2006, p. 1). Sue Gardiner (2006) discusses how Tohi's work of lalava is based on the building up of patterns, lines, and shapes. These layers evoke associations with 
genealogies and reflect spiritual, historical, social, and psychological links.

Running strongly throughout the practice of lalava, and reflected in Tohi's work as well, is the theme of intersection between traditional practices and contemporary abstraction. Moving back and forth and in and out of pattern, he deconstructs the spaces and lines, paring back the components to seek the minimal (Gardiner, 2006, p. 53).

Tongan artist Semisi Potauaine also gave me an opening to advance my reading of vā, and therefore my methodology. Potauaine's (2011) practical work from his thesis Tectonic of the fale: four dimensional, three divisional, is based on highly elaborate and complex geometric kupesi derived from customary Tongan tufunga lalava art. Potauaine states that lalava is the 'manifestation of drawing and making' (S. Potauaine, personal communication, 2011). The commonly used colours in his work - red and black - are culturally and philosophically developed in customary Pacific material arts, such as tattooing, bark-cloth-making, mat-weaving and pottery and, of course, lalava. In considering the information provided by Potauaine, I realised that his expertise in lalava had potential in regard to the binding of cultures. 
The image below is my reinterpretation of Filipe Tohi's sculpture, and it expresses the physical manifestation of lalava. There are six main areas represented:

1 aiga (family)

2 tautala Sāmoa (Sāmoan language)

3 gafa (genealogies)

4 matai (chiefly system)

5 lotu (church)

6 fa'alavelave (ceremonial and other family obligations).

Lala-Vā Model Framework

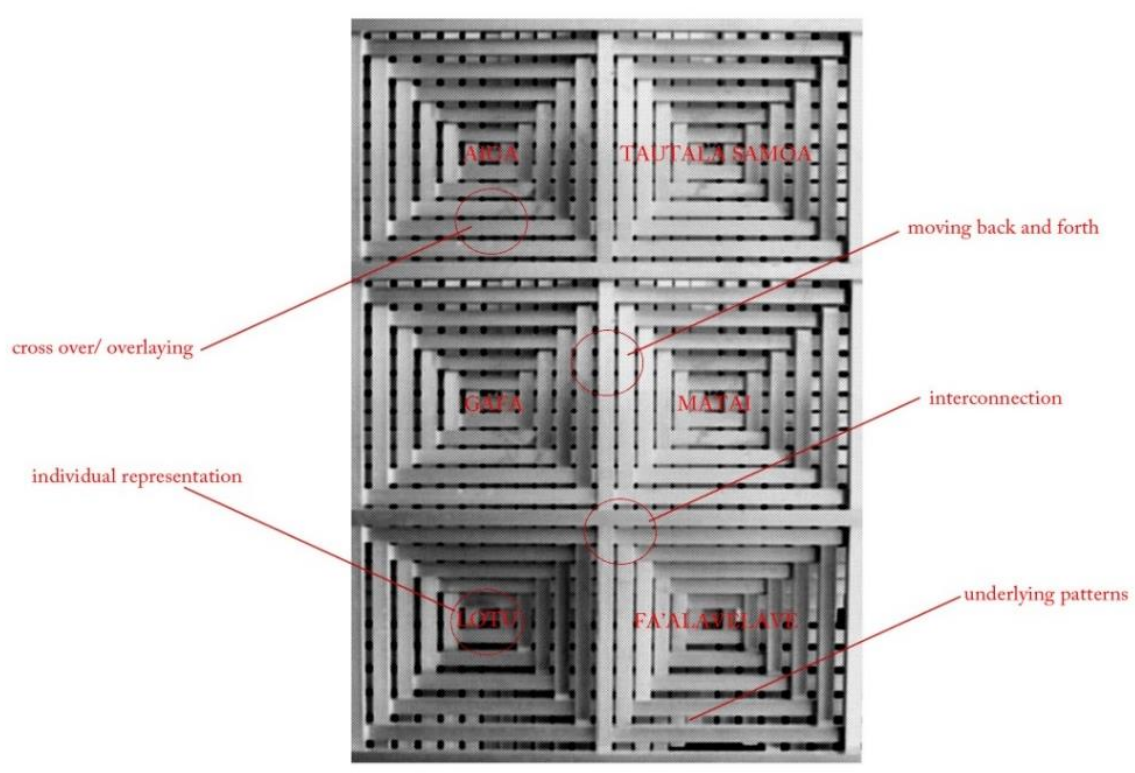


The interconnection of the physical lines in Lala-Vā reinforces aspects of connection and belonging to fa'aSāmoa. Like Tohi's work, they make physical links with one another, and are interdependent on each other. No representation is above the other, as they are all equal, and each needs its length to sustain a coherent system. They formulate a crossover bond, overlaying each other. This repetitive action represents 'moving back and forth and in and out' (Gardiner, 2006, p. 53), the constant negotiation and re-negotiation of space; the vā. The underlying patterns are the relations that are not seen but are still present; they sustain the overall structure and form the bases of the psychological links. This model I designed is derived from the concept of fa'aSāmoa, and is essential to Sāmoan identity.

\section{Lalaga}

Lalaga is the second metaphor I used in developing my methodology. Lalaga is the Sāmoan term for the act of weaving or plaiting. Lalaga - unlike lalava - is a pattern 'technique' used to form goods (e.g 'Ie tōga, mats, baskets, hats, thatching for houses, etc.). Lalaga, I found, is the balance to lalava; it is a technique done by women, which is equally skilful in the craft of pattern. In the past, 'ie togga had a texture like silky linen. They were made from a fine grade of pandanus leaves, dried, scraped, split into 
strips, baked, separated into layers, soaked in the sea, sun-dried, split into fine threads, and finally plaited by hand into a cloth measuring approximately one by two metres (Schoeffel, 1999). As Schoeffel explains, the technique of lalaga does not only refer to the weave (plaiting), but includes the many processes executed prior to the weave.

There are many meanings to the word 'weave' and, for my project, I aspire to lalaga, to interlock the threads of meaning and the threads of vā relations that are active within a community. In this research it is important for me as the researcher to retain the significant meanings of lalava as it ties to fa'aSāmoa, and lalaga as it is essential to Sāmoan identity. The methodological processes of both traditional knowledges can contribute to an epistemology for my Pacific diasporic community project. 


\section{References}

Arendt, H. (2013). The human condition: University of Chicago Press.

Candy, L. (2006). Practice based research: A guide. CCS Report, 1, 1-19. Retrieved from http://www.mangoldinternational.com/fileadmin/Media/References/Pu blications/Downloads/Practice_Based_Research_A Guide.pdf

Flick, U., Kardorff, E. v., \& Steinke, I. (2004). A companion to qualitative research. London: SAGE. Gegeo, D. W., \& Watson-Gegeo, K. A. (2001). "How We Know": Kwara'ae Rural Villagers Doing Indigenous Epistemology. On The Contemporary Pacific: University of Hawai'i Press. Retrieved from http://muse.jhu.edu/journals/contemporary_pacif ic/v013/13.1gegeo01.html

Gegeo, D. W., \& Watson-Gegeo, K. A. (2002). Whose knowledge?: Epistemological collisions in Solomon Islands community development. The Contemporary Pacific, 14(2), 377-409.

Geoff, W. (2006). Doing interpretive research. European Journal of Information Systems, 15(3), 320-330. doi:10.1057/palgrave.ejis.3000589

Halapua, S. (2000). Talanoa process: The case of Fiji. East West Centre, Hawaii.

Hatch, J. A. (2002). Doing Qualitative Research in Education Settings: State University of New York Press. 
Ka'ili, T. (2005). Tauhi va: nurturing Tongan sociospatial ties in Maui and beyond (Vol. 17): University of Hawaii Press. Retrieved from http://aut.summon.serialssolutions.com/2.0.0/lin k/0/eLvHCXMwzZ1LT8JAEMc3hpM3H_jWzIkLIYZ u2VITY4zR4MFwoJzJsN3oHlwSbCF8e

Ka'ili, T. (2008). Tauhi va: Creating beauty through the art of sociospatial relations. University of Washington.

Kirshenblatt- Gimblett, B. (2000). Exhibiting the Other: Museums of Mankind and the Politics of Culture Representation. Reflections.

Kirshenblatt- Gimblett, B. (2002). The Dematerialization of culture and the DeAccessioning of Museum collections. Museum International, 54(4), 58-63.

Maxwell, J. A. (2013). Qualitative research design: an interactive approach (Vol. 41). Thousand Oaks, Calif: SAGE Publications.

Merriam, S. B. (2009). Qualitative research: a guide to design and implementation. San Francisco, Calif: Jossey-Bass.

Ministry of Social Development. (2005). Pacific youth development strategy: Deliver positive life-change and affirmation for all Pacific youth in Auckland. Auckland, New Zealand: Ministry of Social Development.

Moeke-Maxwell, T. (2005). Bi/multiracial Maori women's hybridity in Aotearoa/New Zealand. 
Discourse: studies in the cultural politics of education, 26(4), 497-510.

Schoeffel, P. (1999). Samoan Exchange and 'Fine Mats': An Historical Reconsideration. The Journal of the Polynesian Society, 108(2), 177-148.

Simati-Kumar, B. (2012a). The Potential of Vātransforming Samoan and Pacific communities in the Diaspora. Te Kaharoa: The eJournal of Indigenous Pacific Issues, 11.

Simati-Kumar, B. (2012b). The potential of Vā: an investigation of how 'Ie Tóga activate the spatial relationships of the Vā, for a Samoan diaspora community. AUT University, Auckland. Retrieved from http://hdl.handle.net/10292/4431

Smith, L. T. (1999). Decolonizing methodologies: research and indigenous peoples. Dunedin, N.Z: Zed Books.

Soanes, C., \& Stevenson, A. (Eds.). (2008). Concise oxford english dictionary. New York: NY: Oxford University Press.

Tohi, F. (2006). Sopolemalama Art of lalava. Retrieved 19 March 2010, from http://www.lalava.net/nav.html

Toluta'u, T. K. (2015a). Veitalatala: Matanga 'o e Talanoa. Auckland University of Technology, Auckland University of Technology.

Toluta'u, T. K. (2015b). Veitalatala: Matanga 'oe Talanoa. Auckland University of Technology.

Tsagarousianou, R. (2002). Ethnic community media, community identity and citizenship. In N. J. 
a. O. Prehn (Ed.), Community Media in the Information Age: Perspectives, Findings and Policy. New Jersey: Hampton Press.

Vaioleti, T. M. (2006). Talanoa research methodology: a developing position on pacific research. Waikato Journal of Education, 12, 21-34. Vivieaere, J. (1994). Bottled Ocean. Wellington: Wellington City Gallery.

Wendt, A. (1996). New Zealand electronic poetry centre. Tatauing the post-colonial body, span 42-43, 15-29. Retrieved from http://www.nzepc.auckland.ac.nz/authors/wendt /tatauing.asp. 